\title{
Toisinajattelijoiden julkisuuskuvat
}

Kirjailijoiden julkisuuskuvista ja kirjailijan imagon merkityksestä kirjamarkkinoilla puhutaan nykyisin paljon suomalaisessa mediassa. Myös aiheeseen liittyvä tutkimus on lisääntynyt 2000-luvun kuluessa. Niin elämäkerta- ja autofiktiotutkimus kuin kirjallisuusinstituutiota tarkasteleva tutkimus sivuavat julkisuuden rakentumisen mekanismeja eri näkökulmista. Toisaalta yhteiskuntatieteissä ja mediatutkimuksessa tällä vuosituhannella vauhtia kasvattanut julkisuuskulttuurin tutkimus (celebrity studies) on versonut uutta kirjallisuuden alan kuuluisuuksien tutkimusta. Tämä tutkimusala on omaksunut entistä monitieteisemmän ja monipuolisesti erilaisia menetelmiä hyödyntävän lähestymistavan tutkiessaan, miten kirjailijoiden elämät ja heidän teoksensa vaikuttavat toisiinsa ja miten ne kietoutuvat muihin ei-kirjallisiin diskursseihin sekä sosiaalisiin ja taloudellisiin arvoihin (Braun \& Spiers 2016, 449-450).

Uusia tulokulmia kirjallisuuden ja yhteiskunnallisten ilmiöiden suhteiden tarkasteluun on tuonut etenkin feministisen ja postkoloniaalisen tutkimuksen synty, mutta myös queer-teoria ja ekokritiikki (Braun \& Spiers 2016, 449). Nämä tutkimusalat ovat paljastaneet muu muassa, miten kirjailijan sukupuoli, seksuaalisuus, "rotu" tai etnisyys ovat vaikuttaneet siihen, miten heidän tuotantoaan on arvotettu. Kansainvälinen kirjallisuuden arvoon ja maineeseen, kirjamarkkinoihin sekä kirjailijoiden julkisuuspääomaan ja rooliin poliittisina vaikuttajina tarttuva tutkimus on keskittynyt populaarikulttuurin pohjalta syntyneeseen massakulttuurin aikaan 1900-luvulta eteenpäin, mutta tutkimuksen laajentamista kirjallisuuden kaikkiin lajityyppeihin sekä eri aikojen ja geopoliittisten tilojen kirjallisiin ilmastoihin pidetään tärkeänä (Ohlsson, Forslid \& Steiner 2014). Esimerkiksi 1800-luvun kirjallisen kulttuurin kukoistuksen olennaisia kytköksiä voimistuvaan julkisuuskulttuuriin onkin tutkittu kuluneen vuosikymmenen aikana ahkerasti (ks. esim. North 2009; Weber 2012; O’Neill 2017).

Kuuluisuuden tutkimuksessa keskeinen kysymys intiimiyden tasoja eri tavoin muokkaavista tekijöistä korostaa näkökulmaa, jossa kirjallisuuden tähtinimiä ei nähdä vain julkisuuden marionetteina vaan julkisuutta aktiivisesti erilaisiin tarkoitusperiin hyödyntävinä ja omien julkisuuskuviensa rakentamiseen osallistuvina (Moran 2000; Marshall 2010; Rojek 2016; Braun \& Spiers 2016). Tästä esimerkkejä ovat kirjailijoiden kannanotot kirjallisuuspalkintojen yhteydessä (ks. esim. Braun 2011) tai yhteiskunnassa vähemmistöön kuuluvien ja toisinajattelijoiden puheenvuorot, kuten irlantilaisen Colm Tóibínin media- 
huomiota herättänyt, Trinity Collegessa pitämä esitelmä siitä, millaista on olla homomies ja kirjailija Irlannissa (Mayer 2017, 152).

Kirjailijoiden julkisuuden dynamiikkaa on käsitelty monin eri tavoin myös kaunokirjallisissa teoksissa itsessään ainakin 1700-luvulta lähtien. Tästä tuoreen esimerkin voisi ottaa vaikkapa Saara Turusen romaanista Järjettömiä asioita (2021), jossa dramaturgiksi ja kirjailijaksi kypsyvä päähenkilö pohtii muun muassa sitä, voiko hän naiskirjailijana kirjoittaa rakkaudesta ollakseen uskottava taitelija sekä miten hänen julkisuuskuvansa kirjailijana rakentuu.

Suomessa julkisuutta on usein pidetty uhkana vakavasti otettavalle kirjailijan uralle. Esimerkiksi Suomen kansainvälisesti menestyneimmän kirjailijan Sofi Oksasen on toisinaan katsottu saavutuksillaan poissulkevan kriittisen kantaaottavuuden mahdollisuuden - ikään kuin julkisuus tai kaupallisuus tärvelisivät Oksasen kritiikin naisiin kohdistuvaa väkivaltaa ja nationalismia kohtaan. Tällöin ajatellaan, että Oksanen ei ole aidosti kiinnostunut esillä pitämistään asioista vaan ne toimivat ainoastaan myynnin edistämisenä. Kirjailijan itsensä ohella perinteinen ja sosiaalinen media eri yleisöineen tuottavat moninaisia käsityksiä, joissa kirjailijan äänen painoarvoa ja uskottavuutta on puntaroitu ennen kaikkea suhteessa sukupuoleen, etnisyyteen ja ulkonäköön luokkaaseman osoittimena. (Lehtonen 2014.)

Tässä numerossa peräti kahdessa esseessä tarkastellaan äskettäin menehtyneen toisinajattelijan elämänkaaren, kirjallisen uran ja julkisuuden suhteita. Samaa sukupolvea edustavat suomenruotsalainen kirjailija Christer Kihlman (1930-2021) ja koko kansan tuntema syväekologi Pentti Linkola (1932-2020) olivat kumpikin eläessään ristiriitaisia hahmoja, jotka osasivat myös hyödyntää julkisuutta ajatustensa ja teostensa käsittelyssä. Suhde julkisuuteen on ollut molemmissa tapauksissa monisyinen ja toisinaan kiusallinenkin. Mikko Carlsonin essee pohtii Kihlmanin ristiriitaista suhdetta julkisuudessa saamaansa leimaan tunnustuskirjailijana, mikä typisti ja jopa ohitti hänen monipuolisen roolinsa yhteiskuntakriitikkona. Carlson korostaa Kihlmanin teosten transgressiivisuutta seksuaalisuuden normien ja homoseksuaalisuuden käsittelyssä. Hieman samaan tapaan kuin Kihlman myös Linkola jäi julkisuudessa rakentuneen roolinsa vangiksi. Mikko Kallionsivu avaa Linkolan ekokriittistä perintöä pohtimalla sitä suhteessa kirjailijan elämäntarinaan, jota väritti solastalgia eli ympäristössä havaitun muutoksen aiheuttama emotionaalis-eksistentiaalinen stressi. Kallionsivu suhteuttaa Linkolan esseistiikkaa ihmisen luonto- ja ympäristösuhteita jäsentävään luontokirjoittamisen kaanoniin, jonka klassikoihin kuuluu muun muassa transsendentalisti Henry David Thoreaun kuuluisa teos Walden: Elämää metsässä (Walden; or, Life in the Woods, 1845).

Numerossa on kolme vertaisarvioitua artikkelia. Salla Rahikkalan postkoloniaalista kirjallisuudentutkimusta sekä kertomusten metamodernismin 
teoriaa hyödyntävä artikkeli analysoi kysymyksiä romaanin, kertomuksen ja mustan subjektiuden rakentumisesta Zadie Smithin teoksessa Swing Time (2016). Romaanissa kertomusten ja kaunokirjallisten keinojen runsaus kiinnittää huomion metanarratiivisesti kertomusten merkitykseen ihmisenä olemiselle. Rahikkala keskittyykin kertomusten moneuteen ja metanarratiivisuuteen ja osoittaa, miten Smithin teos tunnustelee postmodernin jälkeisen kaunokirjallisuuden mahdollisuuksia erityisesti mustan subjektiuden representoimisessa.

Saija Isomaa kartoittaa artikkelissaan kirjallisuudentutkimuksessa esiintyneitä käsityksiä poetiikasta 1800-luvulta nykypäivään asti. Hän hahmottaa historiallista poetiikkaa yhtenä kirjallisuudentutkimuksen suuntauksena, joka keskittyy kirjallisten ilmiöiden historialliseen tarkasteluun, kuvaamiseen ja teoretisointiin. Käsitteellistämällä erilaisia historiallisesti suuntautuneita poetiikan lähestymistapoja Isomaa pyrkii asemoimaan ne tarkemmin kirjallisuudentutkimuksen kentällä ja näin lisäämään tutkimusalan itseymmärrystä ja tutkimussuuntien yhteistyötä.

Rimma Erkko käsittelee artikkelissaan groteskin tematiikkaa ja traumaattista naurua Tomi Kontion palkitussa lastenkirjassa Keväällä isä sai siivet (2000). Groteskin teemat ja keinot palvelevat teoksessa tavoitetta tarkastella kriittisesti auktoriteetteja sekä aikuisten ja lasten valtasuhteita. Erkko tutkii, millaisilla mekanismeilla kauhu ja nauru teoksessa toimivat sekä miten groteskin ambivalentti luonne ilmenee etenkin naurussa, jota Erkko kutsuu traumaattiseksi nauruksi. Traumaattisessa naurussa yhdistyy sekä karnevalistisia ja voimaannuttavia että kammottavia ja melankolisia piirteitä. Erkon mukaan Kontion teos tuo jöröjukkakirjallisuuden perinteen nykypäivään karnevalisoimalla vanhentuneita käsityksiä lapsista ja siten haastamalla lastenkirjallisuuden normeja.

Markku Lehtimäki ja Arja Rosenholm esittelevät Suomen Akatemian rahoittamaa, monitieteistä konsortiohanketta Pohjoisen muuttuva ympäristö: Kulttuuriset representaatiot ja veden käyttötavat (2017-2021). Hankkeessa tutkitaan pohjoisen ympäristön ja arktisten alueiden inhimillisiä ja kulttuurisia merkityksiä. Keskeisenä kysymyksenä on, miltä pohjoinen ja arktinen näyttävät, kun niiden historiaa, maantiedettä, kieliä ja kertomuksia tarkastellaan veden tieteen (akvagrafian), eikä niinkään maantieteen näkökulmasta. Tällöin huomio kohdistuu siihen, millä tavalla pohjoisen ja arktisen vesiä sen eri olomuodoissa kuvataan tekstin ja kuvan keinoin.

Kirja-arvioita tässä numerossa on kolme. Eeva-Liisa Bastmanin arvio käsittelee tilapäärunouteen - johonkin tilaisuuteen ja usein jotakin henkilöä varten laadittuun runouteen - keskittyvää artikkelikokoelmaa Att dikta för livet, döden och evigheten. Tillfällesdiktning under tidigmodern tid (2020), jonka ovat toimittaneet Arne Jönsson, Valborg Lindgärde, Daniel Möller \& Arsenii Vetushko-Kale- 
vich. Heidi Grönstrandin suurennuslasin alla on Elina Armisen, Anna Logrénin ja Erkki Seväsen toimittama, suomalaista kirjamaailmaa ruotiva artikkelikokoelma Kirjallinen elämä markkinaperustaisessa mediayhteiskunnassa (2020). Siru Kainulainen arvioi Elise Nykäsen ja Riikka Rossin toimittamaa Joutsen/ Svanen -erikoisnumeroa (4/2020) Suomalaiset ahdistukset. Kansallinen omakuva ja kielteiset tunteet, jossa tunnetutkimuksen fokuksessa ovat suomalaista tunneyhteisöä rakentavat ja hajottavat kielteiset tunteet erityisesti kirjallisuudessa.

Lotta Kähkönen \& Riitta Jytilä 


\section{Kirjallisuus}

Braun, Rebecca 2011. Fetishising intellectual achievement: the Nobel Prize and European literary celebrity. Celebrity Studies 2 (3), 320-334. DOI: 10.1080/19392397.2011.609340.

Braun, Rebecca \& Emily Spiers 2016. Introduction: re-viewing literary celebrity. Celebrity Studies 7 (4), 449-456. DOI: 10.1080/19392397.2016.1233709.

Lehtonen, Sanna 2013. The Fame and Blame of an Intellectual Coth. Sofi Oksanen (1977). Teoksessa Idolizing Authorship. Literary Celebrity and the Construction of Identity, 1800 to the Present. Eds Caston Franssen \& Rick Honings. Amsterdam: Amsterdam University Press, 257-273. DOI: 10.1093/fmls/cqx058.

Marshall, P. David 2010. The promotion and presentation of the self: celebrity as marker of presentational media. Celebrity Studies 1 (1), 35-48. DOI: 10.1080/19392390903519057.

Mayer, Sandra 2017. Introduction: art and action: authorship, politics and celebrity. Celebrity Studies 8 (1), 152-156. DOI: 10. 1080/19392397.2016.1275328.

Moran, Joe 2000. Star Authors: Literary Celebrities in America. London: Pluto.

North, Julian 2009. The Domestication of Cenius: Biography and the Romantic Poet. Oxford \& New York: Oxford University Press. DOI: 10.1093/acprof:0so/9780199571987.003.0003.

Ohlson, Anders, Torbjörn Forslid \& Ann Steiner 2014. Literary Celebrity Reconsidered. Celebrity Studies 5(1-2), 32-44. DOI: 10.1080/19392397.2014.887533.

O'Neill, Bonnie Carr 2017. Literary Celebrity and Public Life in the Nineteenth-Century United States. Athens, CA: The University of Ceorgia Press. DOI: 10.2307/j.ctt1pwt6fo.

Rojek, Chris 2016. Presumed Intimacy: Parasocial Interaction in Media, Society and Celebrity Culture. Cambridge: Polity.

Weber, Brenda R. 2012. Literary Women and Literary Celebrity in the Nineteenth Century: The Transatlantic Production of Fame and Cender. London \& New York: Routledge. 